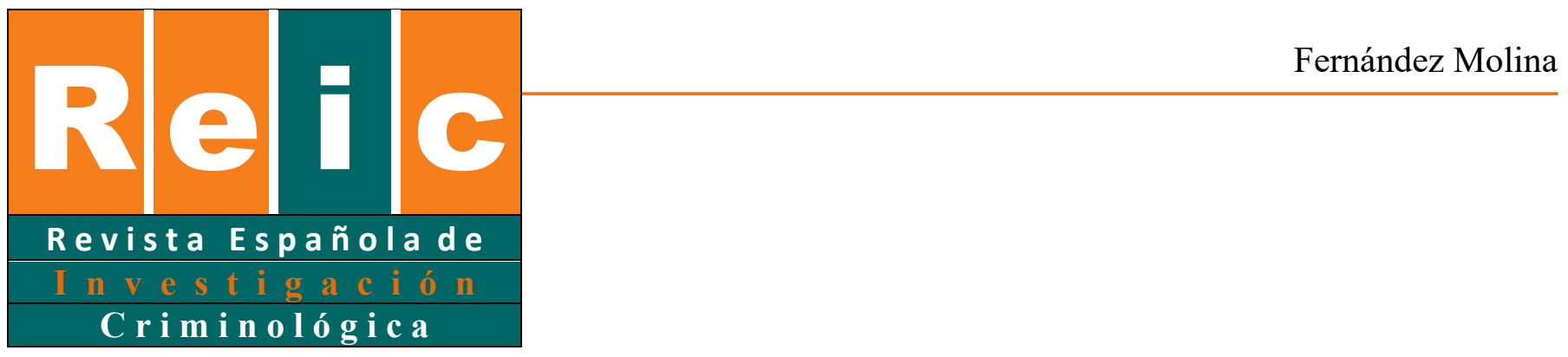

\title{
Editorial
}

Esther Fernández Molina

Editora-Jefa REIC

Universidad de Castilla - La Mancha

\section{Avances de la REIC en 2020 y retos para el 2021}

Me complace presentar a los socios de la Sociedad Española de Investigación Criminológica (SEIC) y a todos los lectores de la Revista Española de Investigación Criminológica (REIC) el nuevo número correspondiente a 2021. Son ya 19 los números publicados con los que esta publicación especializada ha logrado hacerse un hueco en el mundo editorial de las ciencias sociales y jurídicas españolas. Son ya 19 años en los que la SEIC, a través de su revista, ha logrado promover la investigación criminológica, especialmente española, y con ello ha contribuido al desarrollo de esta disciplina en nuestro país.

2020 no ha sido un año fácil para nadie y cada uno de nosotros ha tenido que sacar lo mejor de sí mismo para seguir el camino, a pesar de las dificultades que la crisis sanitaria ha generado. Desde la dificultad y con los sacrificios personales que todos hemos tenido que hacer, la comunidad científica ha seguido trabajando durante esta crisis con más energía y esfuerzo que nunca. Todas las ciencias han tratado de aportar conocimiento para plantar cara a este virus o a sus devastadores efectos. Así, desde el recogimiento al que nos ha llevado la pandemia los científicos sociales han explorado el impacto que la grave crisis sanitaria ha provocado en nuestra sociedad.

Revista Española de Investigación Criminológica

Editorial, Volumen 19(1) (2021)

https://doi.org/10.46381/reic.v19i1.553

www.criminologia.net

ISSN: 1696-9219 
A pesar de la dificultad, 2020 ha sido un buen año para esta revista que ha venido a recoger los frutos sembrados durante tantos años por los excelentes editores con los que ha contado. Me alegra, como nueva Editora de la REIC, ser portavoz de buenas noticias y poder contar los logros alcanzados.

En primer lugar, me gustaría destacar que en el volumen 18 de la REIC se han publicado 9 artículos en el número ordinario. Además, por primera vez, se ha logrado publicar un número especial con 7 artículos. El número ordinario es un reflejo de la calidad creciente que tienen los trabajos criminológicos realizados en España, que abarcan una amplia variedad de temas y que ha contado, entre otros, con autores consolidados y reconocidos como José Cid y Elena Larrauri. Asimismo, cuenta con artículos de investigadores externos a la SEIC como Ma José Cantero, Ascensión Ruíz o Nigel South y jóvenes investigadores como Úrsula Ruíz, José María López Riba, Marta Martí o Marc Salat.

Por su parte el número especial publicado en inglés sobre "Immigration, Crime and Punishment" ha sido editado por Elisa García España, José Ángel Brandariz y Cristina Fernández Bessa. Este monográfico surgió como una iniciativa promovida desde el grupo de trabajo sobre Inmigración y control social de la SEIC y ha servido para mostrar el gran trabajo que se está realizando desde los grupos de trabajo de la Sociedad. Además, este número especial ha servido para visibilizar la situación de vulnerabilidad y exclusión que viven los migrantes y cómo los hallazgos recogidos podrían ayudar a desarrollar políticas y estrategias de actuación más eficaces para su protección. La iniciativa de este grupo ha servido como revulsivo para otros grupos de trabajo, de tal manera que es un placer comunicar que ya está en marcha la edición de otro número especial, a cargo del grupo de trabajo de Criminología cuantitativa sobre "Fuentes de datos para la investigación de la delincuencia en España", previsto para el volumen 19.

También puedo avanzar logros en el reconocimiento del impacto de la REIC. Durante este 2020 la revista se ha adherido al movimiento de revistas Open Access habiendo sido incluida en el Directory of Open Access Journal (DOAJ), lo que, entre otras cosas, ha contribuido a aumentar el índice ICDS que elabora el instrumento MIAR. De igual modo el índice de creciente creación DIALNET METRICS ha clasificado a la REIC en el primer

\section{Revista Española de Investigación Criminológica}

Editorial, Volumen 19(1) (2021)

https://doi.org/10.46381/reic.v19i1.553

www.criminologia.net

ISSN: 1696-9219 
cuartil en el ámbito de las revistas de Sociología. En el camino para conseguir el reconocimiento de la calidad, la REIC ha presentado al inicio de este 2021dos solicitudes, una, para su inclusión en el catálogo SCOPUS y, otra, en el catálogo de revistas de FECYT. Para preparar estas solicitudes ha sido necesario revisar algunos aspectos del código ético de la revista. Así, y siguiendo los criterios del Comité de ética de Publicaciones (COPE), se han revisado los criterios de corrección de errores y retirada de artículos, se ha diseñado una política de depósito de datos de investigación y también se ha formulado una política de autoría científica a la que deberán someterse los autores que envíen manuscritos a la REIC.

Asimismo, ha habido que realizar un nuevo esfuerzo para incrementar las posibilidades que ofrece la plataforma de Open Journal System para la gestión editorial y se han realizado modificaciones relevantes en la interfaz de la REIC. Por ejemplo, en la actualidad es más fácil identificar la visibilidad y el impacto que tiene cada artículo, también ha sido publicada la información general sobre artículos más leídos y descargados, las estadísticas de gestión editorial y el listado de revisores. Para llevar a cabo todas estas mejoras la REIC está en deuda con Bertha Prado Manrique, asistente editorial de la revista, que ha peleado durante muchas horas con la plataforma para que la revista estuviera a punto para presentar las solicitudes mencionadas.

Tan solo me queda reconocer que ninguno de los logros mencionados se habría alcanzado sin contar con el trabajo de los principales responsables del contenido de los 19 números publicados: los autores que, como decía, demuestran año a año el nivel y la calidad científica creciente que tienen las investigaciones criminológicas realizadas mayoritariamente en España. De igual forma, el invisible y abnegado esfuerzo que realizan los revisores para conseguir la mejor versión de cada trabajo. Para todos ellos el reconocimiento de todo el equipo editorial.

Por último, me gustaría indicar cuáles son los retos que el nuevo equipo editorial se ha marcado para los próximos años y que, como es natural, parten del objetivo que la SEIC le ha atribuido como publicación oficial de la Sociedad. En primer lugar, la REIC aspira a consolidarse como una publicación de referencia en el ámbito de la Criminología. Esa consolidación pasa hoy día por su inclusión en bases de datos especializadas y alcanzar un

\section{Revista Española de Investigación Criminológica}

Editorial, Volumen 19(1) (2021)

https://doi.org/10.46381/reic.v19i1.553

www.criminologia.net

ISSN: 1696-9219 
alto índice de impacto. Como decía, en este 2021 se ha iniciado ya este proceso y en el horizonte más inmediato está realizar nuevas solicitudes, entre ellas la inclusión de la REIC en Emerging Sources Citation Index que elabora Clarivate Analytics, como paso previo al objetivo colectivo de que la revista sea incluida en el Journal of Citation Report. En segundo lugar, me gustaría recordar que la REIC nació con vocación de ser un canal principal para la difusión de la investigación científica en Criminología desarrollada en España, pero también en Latinoamérica. De ahí que este equipo editorial aspire a conseguir una mayor proyección y difusión de la revista en los países latinoamericanos, con el objetivo de convertirse también en una publicación de referencia para la creciente producción de alta calidad científica que desde allí se está llevando a cabo. Esperemos que el nuevo año traiga buenas noticias y esperanza para todos y en todos los ámbitos. 